\title{
Uplift Quantification and Erosion Rate Estimation in Northwestern Tunisia from Topographic and Lithologic Data
}

\author{
Hania Saadouni ${ }^{1} \&$ Rabah Alouani $^{1}$ \\ ${ }^{1}$ Department of Geology, University of Carthage, Bizerte, Tunisia \\ Correspondence: Hania Saadouni, Department of Geology, University of Carthage, 7000 Bizerte, Tunisia. E-mail: \\ hnia16saadouni@hotmail.fr
}

Received: December 20, 2020

Accepted: January 16, $2021 \quad$ Online Published: March 26, 2021

doi:10.5539/ep.v10n1p15

URL: https://doi.org/10.5539/ep.v10n1p15

\begin{abstract}
Digital elevation modeling (DEM) was used to determine key morphological features such as hypsometry, slopes and topographic evolution in correlation with tectonic regimes and erosion mechanisms. This contribution discusses the tectonic model of northern Tunisia, which since 1977 has been described by geologists as an allochthonous unity domain of the Serravallian-Tortonian. This study presents new data from the erosion rate calculation following the establishment of these units and then proposes another view on regional tectonics. Therefore, the example used of Oued Sedjnene gives a rising rate of the order of $0.01 \mathrm{~mm} / \mathrm{year}$, almost equivalent to the results found in surrounding medeterranean belt (ex. Italy and Turkey). The structure and geomorphology of northern Tunisia is a result of folding of Cenozoic basin. However located tangential structure are related to transcurrent faults and not overthrust structure
\end{abstract}

Keywords: Alpine phase, topography, erosion, uplift, digital elevation modeling DEM

\section{Introduction}

The structural pattern of northern Tunisia is considered to be the result of the stacking of the allochthonous unit from the Alpine major phase (Rouvier, 1985; Carr and Miller, 1979). Mollasic basins should normally exist in this pattern to form the isostatic adjustment, yet the structural units do not present upper Miocene mollasic basins. This tangential model assumes that the establishment of the structural units must have occurred just after the Lower Miocene and during the Tortonian. However, nowhere will the Serravallian and the Tortonian be represented by deposits. This poses the real problem on the formation of these structural units. To discuss this evolution we have relied on the ideas of post-nappe isostatic equilibrium and consequently the evaluation of erosion rates (Whipple and Tucker, 2002; Mariantonietta et al., 2019). It is considered that the stacking of the structural units leads to erosion and consequently, to the creation of juxtaposed basins to receive fluvial or marine sediments. Whipple and Tucker (1999), Gallen and Wegmann (2017) and Phillips (2018) incorporate rock uplift, U, into a fluvial erosion model to reach the steady state. To try to elucidate the nature of these structural units in northern Tunisia, we have used a digital terrain modeling (DTM) field to understand and model this dynamic in the context of complex tectonic disturbances, and for more or less constant climatic conditions. We have used a novel experimental device to study the evolution of a surface subjected to the simultaneous action of an uplift and erosion through runoff. This approach makes it possible to become aware not only of the relations between the erosion law, the topography and the uplift rate, and to provide at the end the quantity of deposits that do not exist in a very limited sedimentary basin, but also of a new outlook on the Tertiary geodynamic evolution as confirmed by the Alpine phase.

\section{Geological Setting and Geomorphological Evolution}

Taking into account previous work, the geology of the northwestern tip of Tunisia is marked by a clear structural division (Crampon 1971; Melki 2005) (Fig 1). This division has long been associated with Alpine tectonics with allochthonous units in the north and foreland basins in the south ranging from the Triassic to the Neogene. In the global context of the western Mediterranean, several studies have confirmed tectonic predominance for this period (Ben Ayed, 1986; Sbeik, 2008; Tlig, 2010). This begins in the Lower Miocene with the shearing and overlapfolding that causes the appearance of calc-alkaline granitoids in Galite and Nefza. This Alpine phase is expressed by a Lower Langhian-Serravallian major compression and generates compressive structures associated with welldeveloped plutonism. Distensive tectonics starts at the base of the Tortonian (Middle Miocene), mainly characterized by extensive fracturing accompanied at different scales, by the opening of grabens and semi-grabens. 
Finally, towards the Upper Miocene, another compressive phase evidenced by thrusts and folds generates relaxation movements in a post-orogenic context, concretized by the rise of basaltic rocks in the regions of Nefza and Mogods. Structural units in northwestern Tunisia are dominated by marls and clays with a low carbonate distribution supported by Rouvier's work in 1977 and more recently by El Euchi et al. (2004), Ould Bagga et al. (2006) and Talbi et al. (2008). These series can reach maximum altitudes of $650 \mathrm{~m}$, and so three main series are identified: the Tellian series, the Numidian series and the flysch domain.

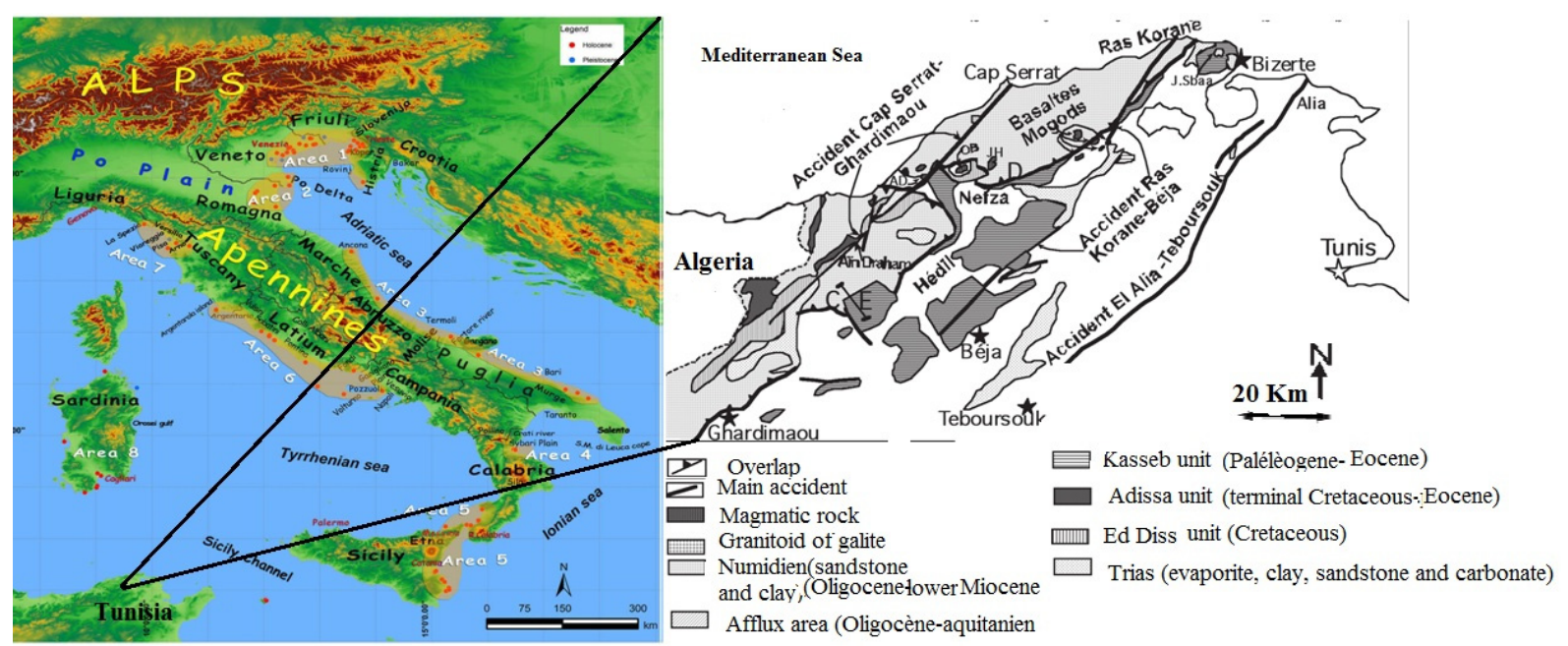

Figure 1. Simplified geological map of northern Tunisia (Talbi et al., 2008)

\subsection{The Tellian Series}

It is the easternmost segment of the Maghreb's Alpine chain, covered by the reliefs of the Kroumirie ranges to the west and the Mogods range to the east. This particular structural domain which runs from the Melloula border crossing to Ras El Koran (NW of Bizerte) (Fig. 2) is composed of the superposition of non-native units or thrust sheets based on an autochthonous and para-autochthonous foreland and extends $150 \mathrm{~km}$ from the SW towards the NE (Rouvier, 1985).

\section{NS}

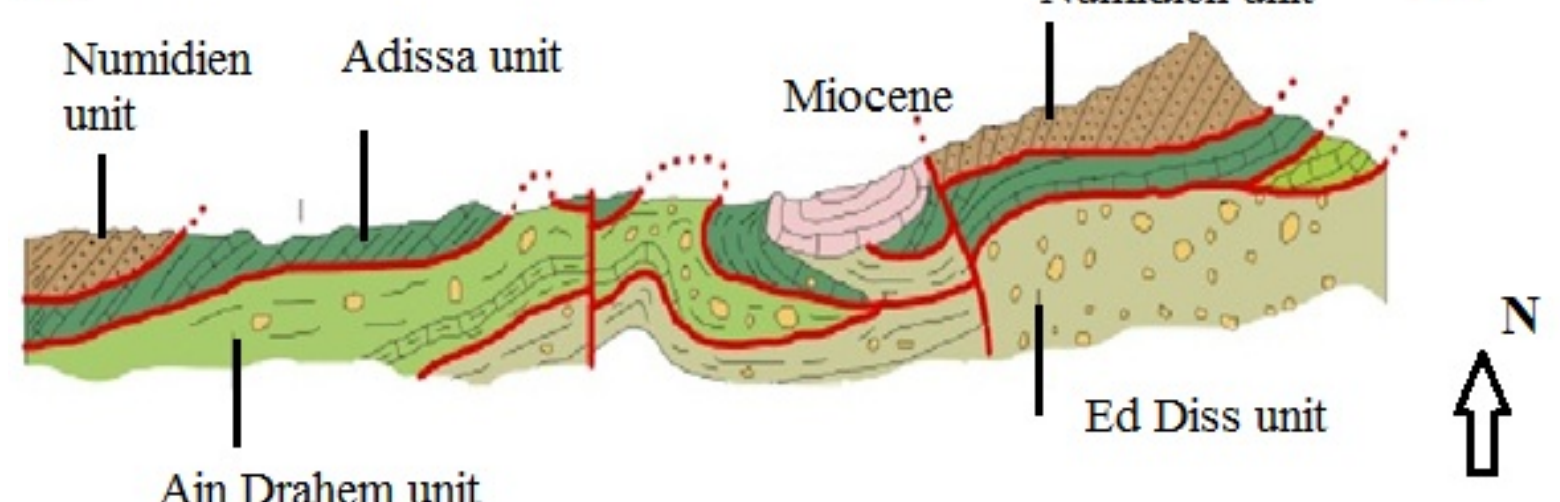

Figure 2. Allochthonous units of the tellienne chain (Rouvier, 1985)

\subsubsection{The Numidian Chain}

It covers almost the whole of the Tunisian far north and is composed of the Kroumirie and Mogod chains, with the exception of the Nefza half-window, and mainly consists of layers of clay and sandstone with a base with a major abnormal contact (Wildi, 1983; Beaudoin et al., 1987; Talbi, 1998; Melki et al., 2001) which separates it from other non-native units (Kasseb, Ed Diss, Adissa and Ain Drahem). 


\subsubsection{The Flysch Domain}

This area in northern Tunisia is composed of Oligocene-Lower Miocene turbidite facies that can exceed $2000 \mathrm{~m}$ in thickness and is also composed of the North African Tethys (Wildi, 1983; Guerrera et al.). This area has therefore been identified as peri-Mediterranean subsidence basins trapping the Numidian flysch (Carr and Miller, 1979). Tectonic activity has caused normal faults (Frizon de Lamotte et al., 2006; Koçyiğit et al., 2013) probably related to the Oligocene rifting phase in the western Mediterranean (Rehault et al., 1984; Watts et al., 1993; Doglioni, 2011). The basins that trapped these flysches disappeared during the Miocene orogenic phases. The Oligocene and the Lower Miocene widely cover the country with a total thickness that reaches 3000 meters. In the extreme north, at the nappe zone level, the allochthonous Tellian units are covered by a thick clay-sandstone formation, an abnormal contact. The presence of turbidites, slumps, mudslides, and clastic veins indicates deep sea sedimentation (Cairo and Coiffait, 1970; Yaich et al., 2000).

\section{Methodology}

Among other things, we have used digital modeling to study the asymmetry of our study area as well as the joint role of the existence of the initial hydrological zones and a non-negligible erosion threshold on the evolution of the average altitude of the system and the characteristic time required to reach the equilibrium state. The response of the surfaces to different uplift rates makes it possible to study equilibrium relations between mean altitude and tectonic forcing for the specific case of the experimental erosion law. We used the DEM digital surface process model with a higher resolution of $90 \mathrm{~m}$. This model simulates the action of relief distribution data and slopes with a hypsometric analysis. Applied to the experiments, it has made it possible to remove the ambiguity on the sediment transport mode by correctly reproducing the hydrographic network map derived from an altitude model. The model was then used to explore a wider range of erosion and uplift processes. These simulations were used to determine the characteristic forms of topographies in the stationary or transitory state, and made it possible to define morphological criteria to quantify the natural systems' degree of imbalance. The analysis of natural data allowed (1) to characterize the fluvial topographic state and to constrain the elementary erosion laws for systems with dynamic equilibrium, and (2) to highlight a model of topographic evolution to deduce the uplift. Finally, it enabled us to know the reason for the presence of an Upper Miocene sedimentary gap.

\subsection{Topography Digital Modeling}

The topography (or morphology) of a mountain belt reflects the combined effects of climatic, magmatic and tectonic processes (Whipple and Tucker, 1999; Willett et al., 2014; Giachetta and Willett, 2018). Tectonic processes, both vertical and horizontal rock displacements, and magmatic processes (i.e. volcanism) build the topography and are driven by endogenous dynamics. On the other hand, the surface topography treats erosion as a construction and is driven by exogenous dynamics. Montgomery et al. (2001) and Ahmed Laabidi et al. (2016) have shown that the main morphological features such as hypsometry and maximum elevation in correlation with climatic regimes and the mechanisms of erosion and uplift are an important step for the relief hierarchy.

\subsubsection{The Hypsometric Map}

The hypsometric analysis of northwestern Tunisia (Fig. 3) shows a highly varied distribution of altitudes and, according to the classification, it is possible to observe a low occupation of high altitudes which takes us back to the lithological nature of the area characterized by the very low occupation of sandstone and a weak alternation of limestones and marls with dolomite karstic limestones located largely at the northern end, the center and the south.

Just as the hypsometric curve shows a very straight form and weak hypsometric integrals, the elevation-relief ratio indicates a mature landscape (equilibrium stage). Figure 4 shows on the right side of the diagram a common feature known as "shouldering". This shoulder reflects a mass distribution where volume is important at relatively low altitudes. More than $80 \%$ of the area (or volume) was at an altitude less than half of the respective maximum elevation, constituting the structural units of Alpine folding with a rather weak indication of Lower Miocene and the total absence of the Upper Miocene. 


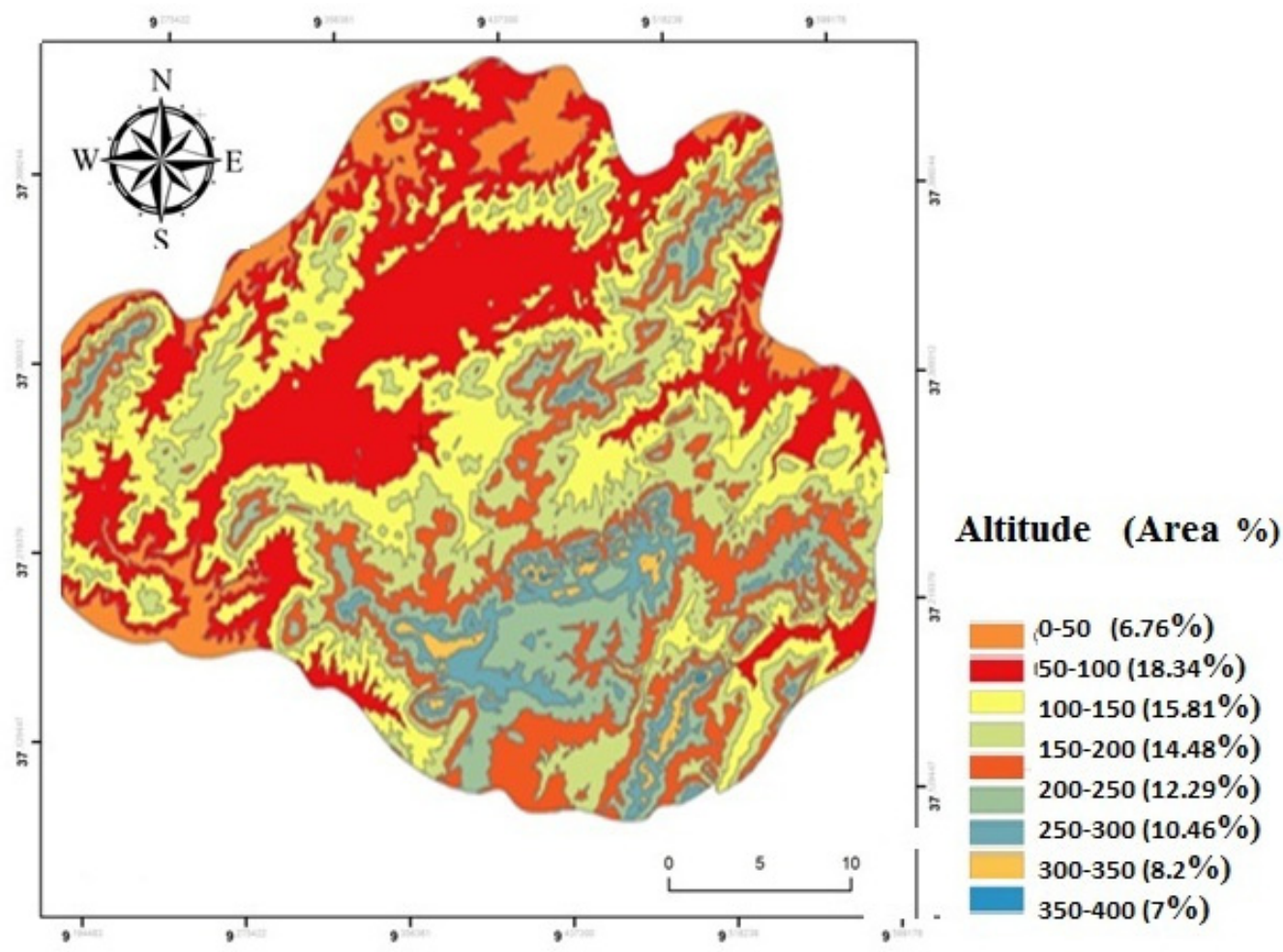

Figure 3. Hypsometric Analysis Map of Northwestern Tunisia

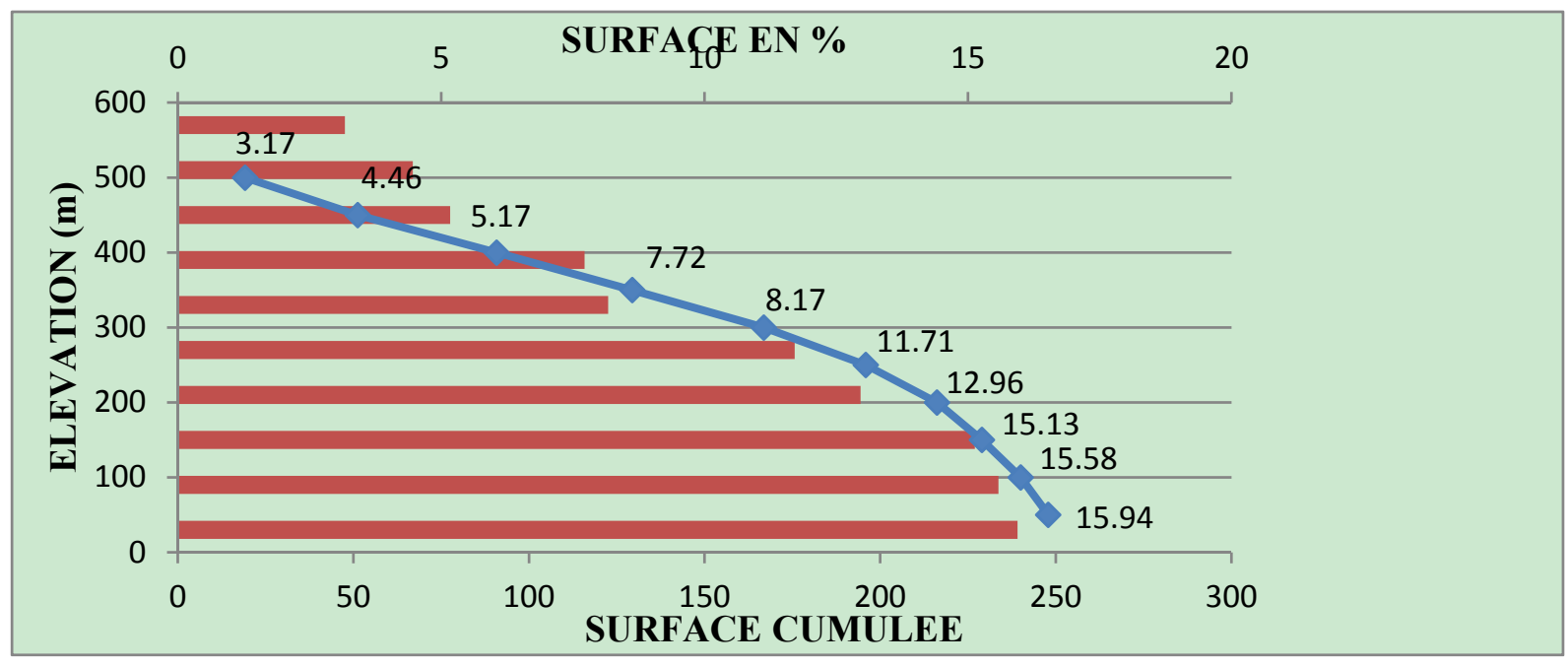

Figure 4. The hypsometric curve

The integral $\mathbf{E}$ of the area is given by the following formula (Pike and Wilson, 1971)

$$
\mathrm{E}=\frac{\text { Emax }- \text { Emin }}{\text { Emoy }- \text { Emin }}
$$

Where $\mathrm{E}_{\max }$ indicates the maximum elevation, $\mathrm{E}_{\min }$ the minimum elevation and $\mathrm{E}_{\mathrm{av}}$ the average elevation.

$$
\mathrm{E}=\frac{176-0}{503-0}=0.34
$$

It can be interpreted from Equation 1 that the characteristic shoulder in hypsometry results from the fluvial erosion 
processes, which preferentially erode the higher parts of the chain. If this idea is valid, it is necessary to wait for the development of a shoulder in hypsometry to correlate with other morphometric parameters indicative of erosion, for example with maximum and average altitude and slope. This is not the case: the hypsometric shoulder is a common feature to all domains. In contrast, averages, and maximum continuous elevations decrease in the foreland region to the southeast.

\subsubsection{The Slope Map}

The slope map (Fig. 5) shows a significant distribution of low-to-medium slopes in the northern end with a scarcity of steep slopes towards the south. In the slope frequency plot, the ordinate represents the surface fraction and thea specific slope is given by the abscissa. The diagram shows a trend towards less steep slopes for Miocene units compared to the southern Eocene-Oligocene age zone (Fig. 6): zones dominated by an almost flat slope as indicated by the elevated fraction with slope angles of less than 5-10 ${ }^{\circ}$ which represent Pliocene lavas with a Quaternary plateau. On the other hand, the parts dominated by a wider slope distribution with a $0^{\circ}$ peak representing river systems such as the Oued Sedjnene and a plateau-like slope distribution of up to a $30^{\circ}$ slope angle. The average slopes are about $2^{\circ}$ in some parts and significantly higher with values of around $19^{\circ}$ in others. It can be seen that the slope distribution is correlated with the hypsometric shoulder meaning that erosion was very efficient before the Miocene (the Tellian, Numidian and Flysch series).

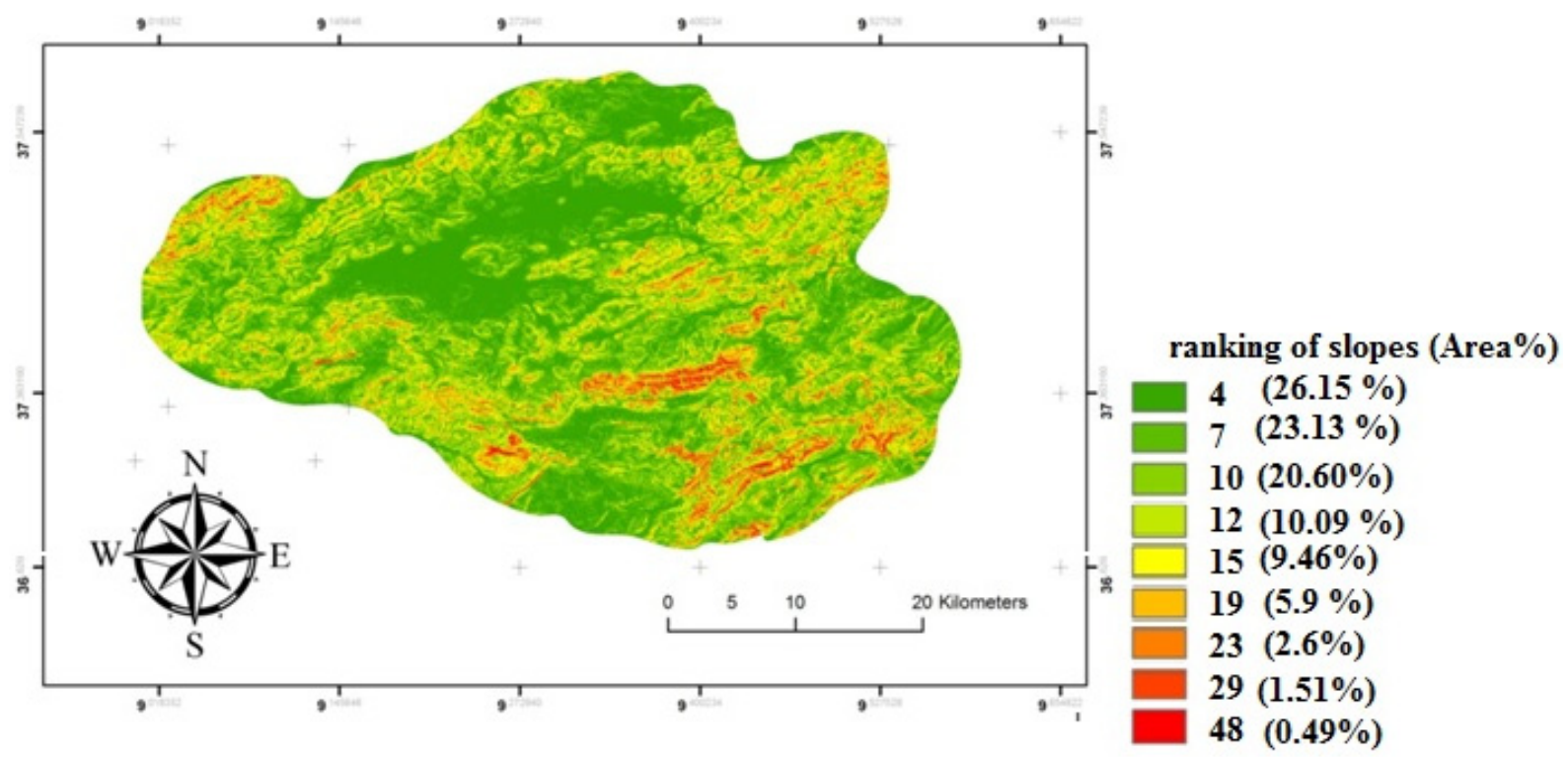

Figure 5. Slope map of the study area

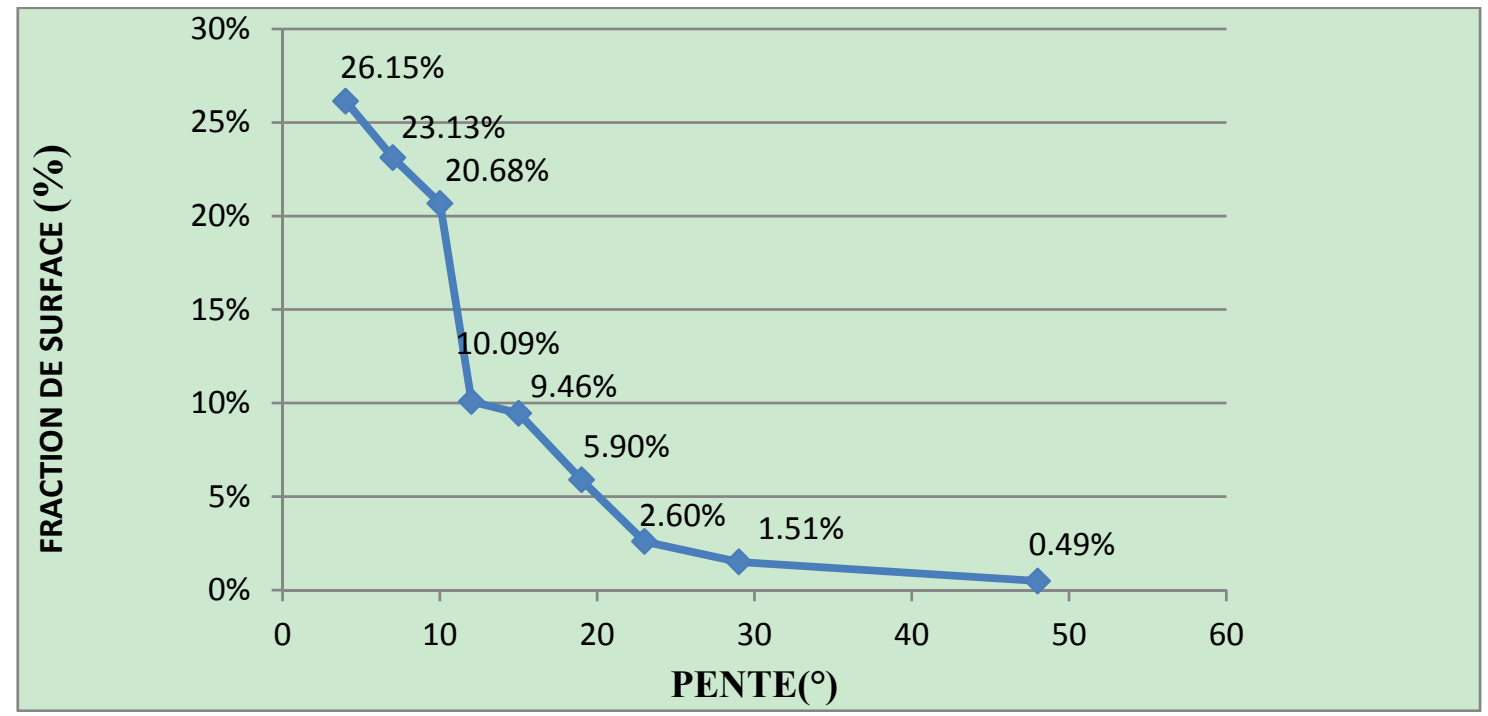

Figure 6. Slope variation diagram 


\subsubsection{Representation of the Drainage Networks (Oued Sedjnene)}

The hydrologic modeling tools provided in the GIS (Spatial Analyst) Arc Expansion Toolkit provide methods for describing the physical components of a surface. We will use a compilation of hydrographic analyses by Phillips and Lutz (2008) to identify basins, determine flow direction, calculate flow accumulation, delineate watersheds and create river systems. The image below (Fig.7) illustrates a hydrographic network derived from an altitude model. Using an elevation raster or digital terrain model (DTM) as an input, it is possible to automatically delineate a drainage system and quantify its characteristics (Schwanghart et al., 2014). The area is well limited by flow, but Oued Sedjnene is the most important drainage system. The slope map shows a very slight slope since more than $70 \%$ of the slopes are between $2^{\circ}$ and $3^{\circ}$. Large factors are used to calculate deposit losses at a given location. Each factor is a numerical estimate of a specific component that affects the severity of material erosion at a given location. The erosion values obtained by applying these factors may vary considerably due to the different weather conditions. As a result, the USLE (Universal Soil Loss Equation) values more accurately represent long-term averages (Stone and Hilborn, 2000).

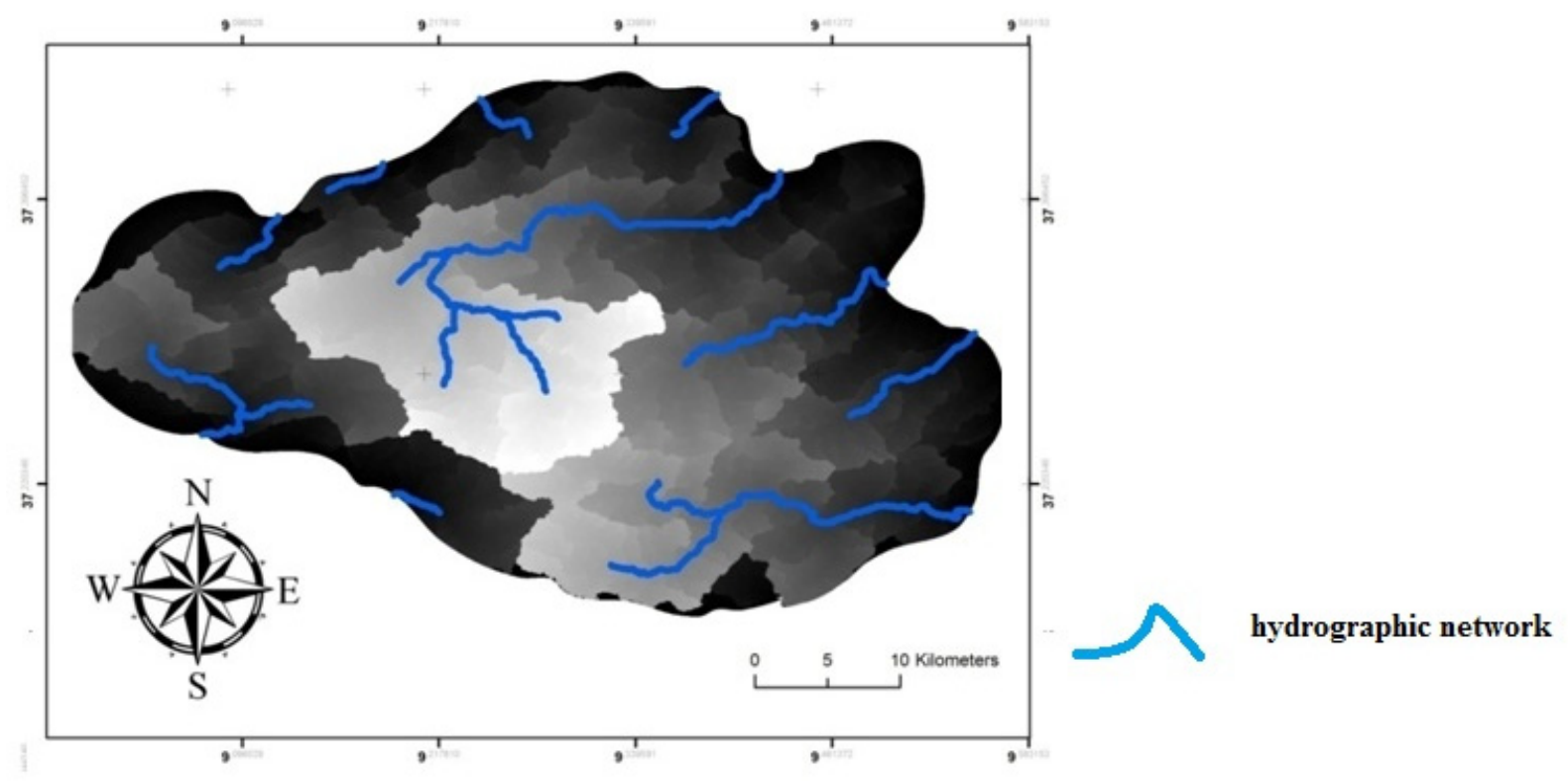

Figure 7. Hydrographic network map derived from an altitude model

It should be well noted though that morphological systems are the key to explaining the forms derived from tectonics, erosion and isostatic equilibrium. The coupling between these phenomena requires intensive erosion after each mountainous creation in a sedimentary basin to reach the equilibrium state. This however is not our case since as a result of the comparison with the previous field literature, we can say that the volume of the eroded Eocene-Oligocene sediment is almost negligible in the field so it is attributed to the Miocene detrital and clay series. It must be emphasized first of all that, despite all its merits and the remarkable contributions of digital terrain models, even though they constitute a very powerful data of analysis, IT alone cannot solve all geological, geomorphological, topographical and planning problems. It would require complementary approaches based on the reality on the terrain. During the field mission in 2019, we stratigraphically (rock face) characterized the nature of the plains (Fig. 8) and the structural units are characterized by marine facies composed of fine beige limestone with Eocene globigerina (about 56 Ma, Ypresian) (Alouani et al., 1996) covered by a continental facies represented by reddish-grey Mio-Plio-Quaternary conglomeratic deposits. This series ends with a gravel slab (1.5 m) (Fig. 8). The lack of structural unit for 31 million years was noted. 


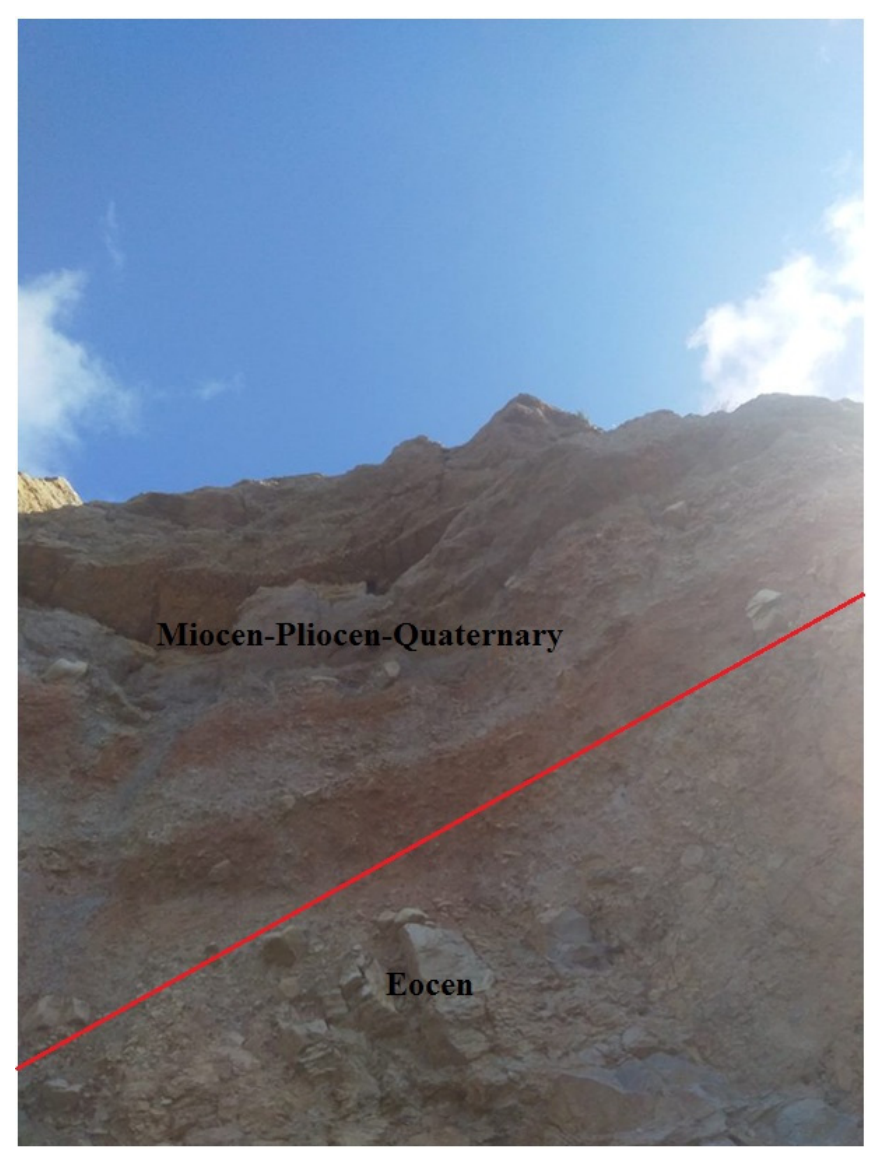

Figure 8. The main morphological marker of the Eocene on northwestern Tunisia

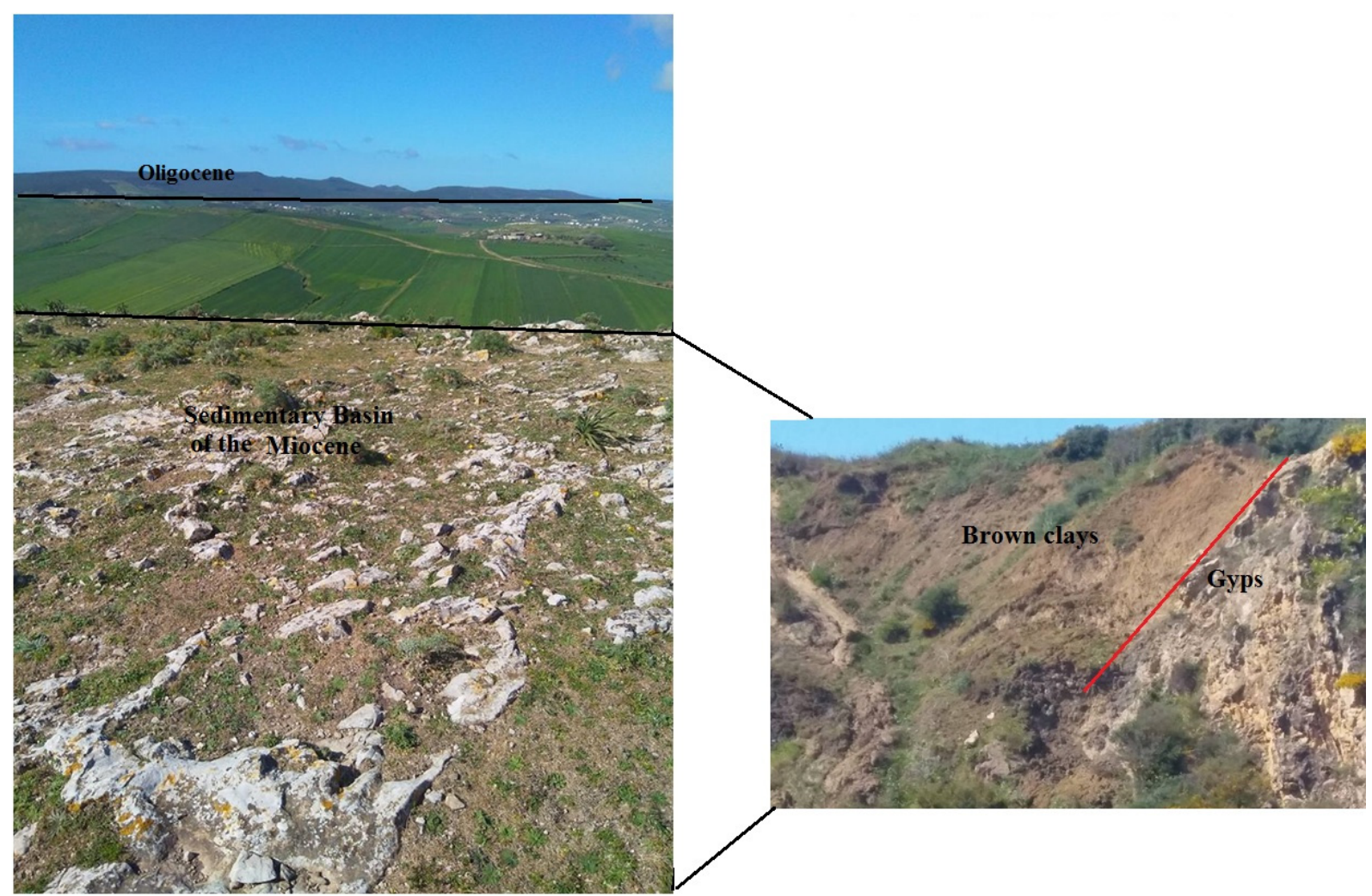

Figure 9. The Miocene sedimentary basin 
We consider that if the stacking of the structural units involves erosion and consequently the creation of juxtaposed basins to receive these sediments, then the verification of the Lower Miocene sedimentary basins would show alternating brown clays and gyps.

\section{Results and Discussion}

\subsection{Fluvial Erosion Model}

\subsubsection{LS Factor}

There are many different equations available for calculating the LS factor with ArcGIS. Bizuwerk et al. (2008) showed that the slope length and inclination can be used in a single index which expresses the relationship between the different losses in deposits as defined by (Wischmeier and Smith, 1978; Bizuwerk et al., 2008) as shown below

$$
\mathrm{LS}=\mathrm{X}^{\mathrm{m}}\left(0,065+0,045 \mathrm{~S}+0,0065 \mathrm{~S}^{2}\right)
$$

Where $\mathrm{X}$ indicates the length of the slope and $\mathrm{S}$ the gradient of the slope

The values of $\mathrm{X}$ and $\mathrm{S}$ can be obtained from the digital elevation model DEM. To compute the $\mathrm{X}$ value, flow accumulation was decreased from DEM after conducting direction and fill processes in ArcGIS.

$\mathrm{X}=($ flow accumulation $*$ resolution) $(3)$

Substituting the $\mathrm{X}$ into the equation:

$$
\mathrm{LS}=\left(\text { flow accumulation } * \frac{\text { resolution }}{22.1}\right)^{\mathrm{m}}\left(0.065+0.045 \mathrm{~S}+0.0065 \mathrm{~S}^{2}\right)
$$

For a stable state of the landscape, where the channel incision rate is equal to the rock uplift rate, $\mathrm{dz} / \mathrm{dt}=0$, and Equation 1 can be solved as follows:

The slope length is the distance from the point of origin of the surface flow to the point where the slope decreases enough so that the deposition begins where the point where the flow is concentrated in a defined channel. The steepness of the slope reflects the influence of the slope on the material erosion (Renard et al., 1997). It is known that the runoff amount increases as the continuous accumulation along the length of the slope (L factor) increases (Fig. 10), and that the runoff rate increases as the slope stiffness (factor S) increases (Kim, 2006).

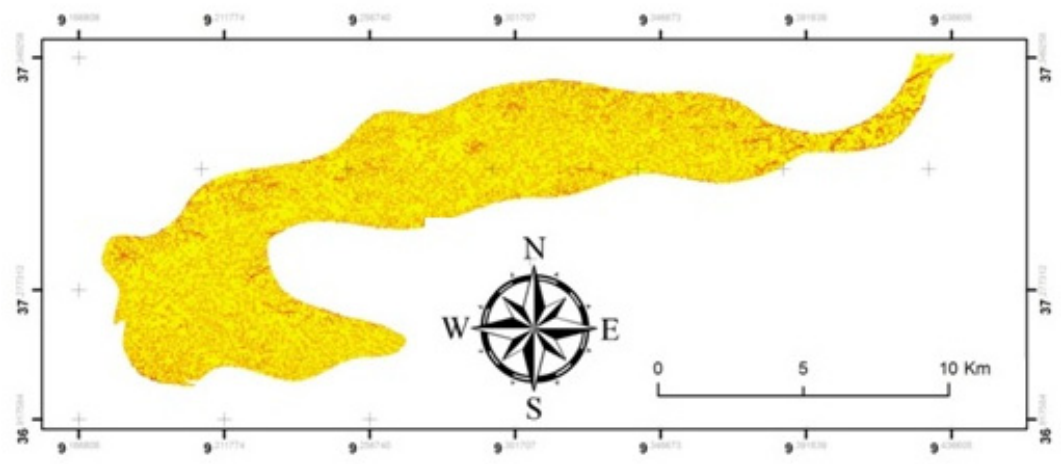

LS Factor

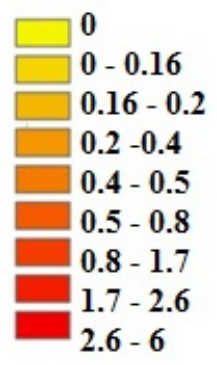

Figure 10. Distribution of the topographic factor

The slope value was taken from DEM using the ArcGIS software and the value of $m$ was obtained from the following table: 
Table 1. Value of $\mathrm{m}$ (Wischmeier and Smith, (1978)

\begin{tabular}{ll}
\hline Value $(\mathrm{m}=$ function of basin hydrology $)$ & slop $\left(^{\circ}\right)$ \\
\hline 0,5 & $>5$ \\
0,4 & $3-5$ \\
0,3 & $1-3$ \\
0,2 & $<1$ \\
\hline
\end{tabular}

As long as more than $80 \%$ of the map slopes are between $2-3$, so $m=0.3$, then the calculation of the slope length and the inclination factor characterizing the relief effect (LS) are obtained from the digital terrain model (DTM) and based on the slope map (Lilia ben Cheik and Moncef Guedderi, 2008). The highest values are logically located in the upstream part of Oued Sedjnene and reach a maximum of 6.018 (Fig.8) for a steeper slope, so it can be deduced that the slope length of Oued Sedjnene is $1600 \mathrm{ft}(488 \mathrm{~m})$. According to the USLE (the Universal Soil Loss Equation), the steeper and longer the slope, the higher the risk of erosion. The sediment influx rate in the study area provides first-order control along the $488 \mathrm{~m}$ stratification architecture. Despite its importance, however, little is known about how sediment flux varies with morphotectonic processes in the source terrain. Faiza Hallouz et al. (2017) noted lithological variations in the more or less hard bedrock (marly to sandstone in our case), changes in drainage and temporary sediment storage patterns in basins.

\subsubsection{Estimation of the Erosion Rate}

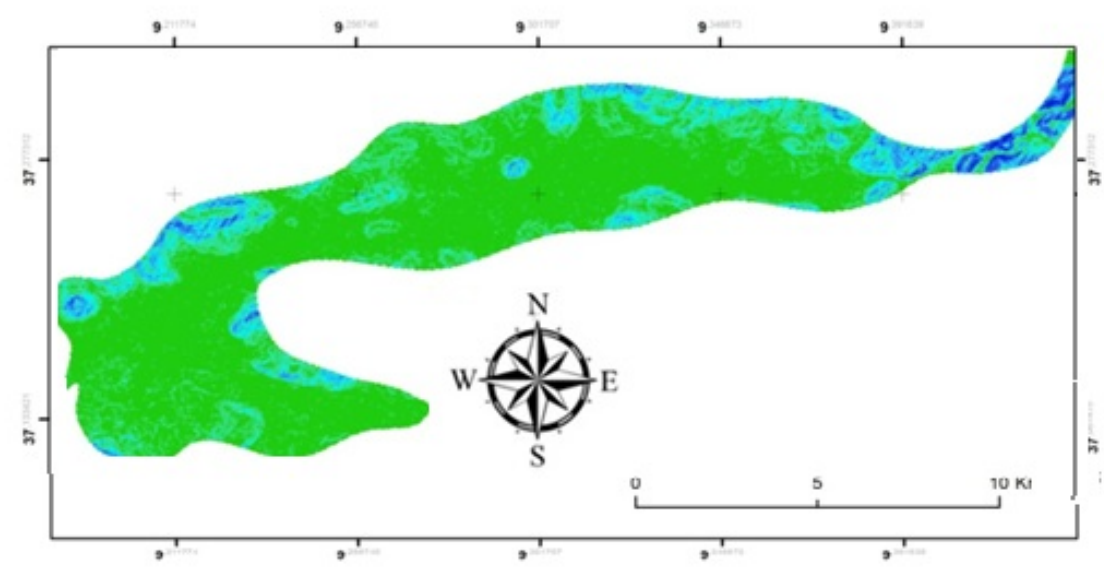

\section{Rates of erosion (m)}

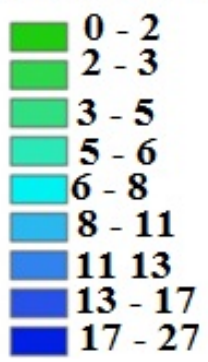

Figure 11. Erosion rate map in (m) Sedjnene wadi

In this study, this factor is explored with a topographic evolution mathematical model that combines fluvial erosion with folding and kinematic thrust (Whipple and Tucker, 2002; Mariantonietta et al., 2019). The model is calibrated by comparing the topographic relief with the relief measured from the DTM in the mountains of northwestern Tunisia. The previous results show that erosion has accurately scraped the amount of materials considered a surplus and removed them in a sedimentary basin and at time t. To define these amounts that are to be removed there are several erosion models mentioned in the literature. Most of them involve a topographic profile above which any generated relief is systematically eroded. When this profile is horizontal, anything that exceeds a certain altitude is removed. Oued Sedjnene is the drainage system located at the level of the overlap escarpments and fluviatile 
models are applied (Fig. 11). The most commonly used fluvial law uses the relationship between the drainage area and the channel gradient (Howard, 1980; Perron and Royden, 2013; Yang et al., 2015).

$$
\varepsilon=\mathrm{KA}^{\mathrm{m}} \mathbf{S}^{\mathbf{n}}
$$

Where $\mathrm{A}$ indicates the drainage area, $\mathrm{S}$ is the channel gradient, $\mathrm{K}$ is an erosion coefficient that denotes information about lithology, climate, and channel geometry (Whipple and Tucker, 1999), and m, $\mathrm{n}$ are positive constants where $\mathrm{m}$ and $\mathrm{n}$ are functions of basin hydrology and the specific incision process respectively (Howard et al., 1994; Whipple and Tucker, 1999; Whipple et al., 2004). Depending on the value of $m$ and $n$, equation (1) can be used to represent shear stresses for various beds ( $\mathrm{m}$ about 0.3, $\mathrm{n}$ about 0.7) (Whipple and Tucker, 1999). The modeling is carried out on Eocene Oligocene and Miocene age series, the erosion rate in Oued Sedjnene is modeled numerically on the ArcGIS software (Fig.12) and reaches its maximum at $27 \mathrm{~m}$. The coefficient erosion rate $\mathrm{K}=0.1110^{-5}$ $\mathrm{m} /$ year $=0.1110^{-2} \mathrm{~mm} /$ year.

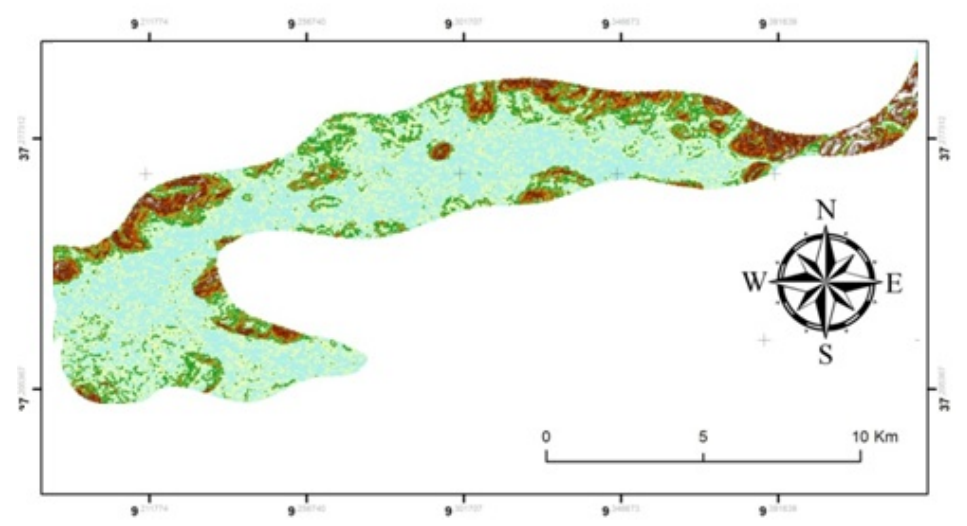

Erodibilty coefficient $\mathrm{K} \mathrm{mm} /$ year

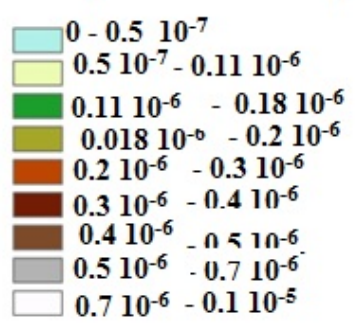

Figure 12. Erosion coefficient map K of Sedjnene wadi

Hence, in the present work, from the erosion information gathered along the nappe areas we can note that after the formation of mountain ranges during the Eocene and Oligocene, the sedimentary basin must have been eroded $127.6^{10} \mathrm{~m}^{2}$ in the Miocene with a volume of 36 million $\mathrm{m}^{3}$. Geological mapping does not confirm the presence of a sedimentary basin in the Upper Miocene that could have received this quantity.

\subsection{Topographic Evolution Model}

The response of the topography to the asymmetrical vertical rock uplift was examined using the fluvial erosion model. The location of major drainage divisions (topographic axes) is of particular importance because these rifts determine top-level topographic features and drainage patterns in mountain ranges, which describe the environment and landscape of the region. This study uses a topographic evolution model by incorporating the effect of rock uplift into a stream erosion model. Under conditions of asymmetric rock uplift, the topographic evolution is simulated numerically, and a curious relationship between the topographic uplift axes and the rock is seen. The dependence of the relationship on exponent values was then studied and its implications and results discussed for true mountain ranges. Rock uplift $U$ is incorporated into the flow erosion model of Equation (1) as in many previous studies (for example Willgoose et al., 1991; Kirkby, 1994; Miller et al.):

$$
\begin{array}{r}
=U-K\left[(A)^{m}(S)^{n}\right] \\
\frac{d h}{d t}=U-\varepsilon \text { so } U=\frac{d h}{d t}+\varepsilon
\end{array}
$$


Where $\mathrm{h}$ represents the current altitude, $\mathrm{U}$ the rock uplift and $\varepsilon$ the erosion rate $=27 \mathrm{~m}$

$$
\frac{a}{b}+c=\frac{a+b c}{b} \text { so } \frac{d h}{d t}+\varepsilon=\frac{d h+\varepsilon d t}{d t}=\frac{h+\varepsilon t}{t}
$$
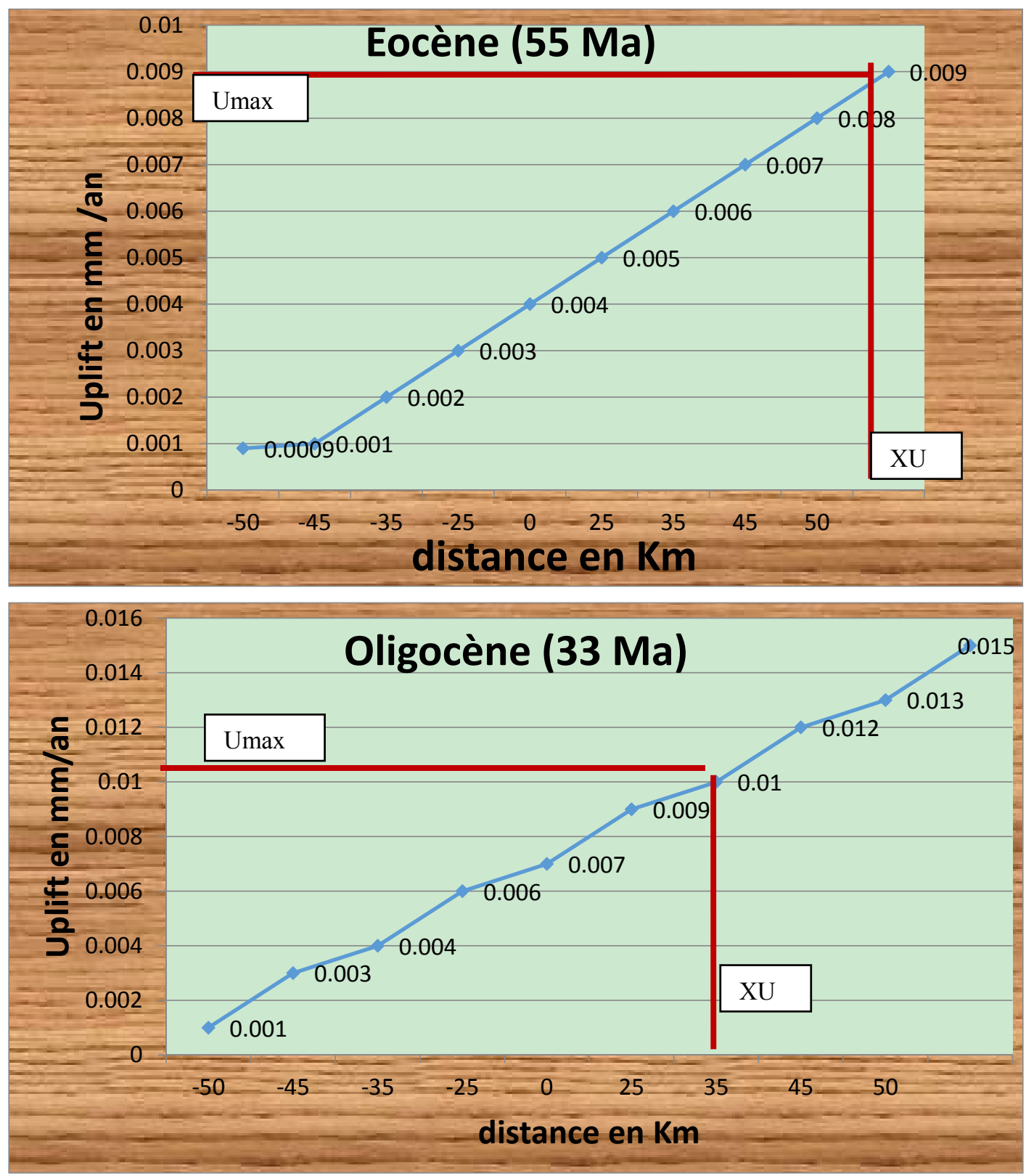


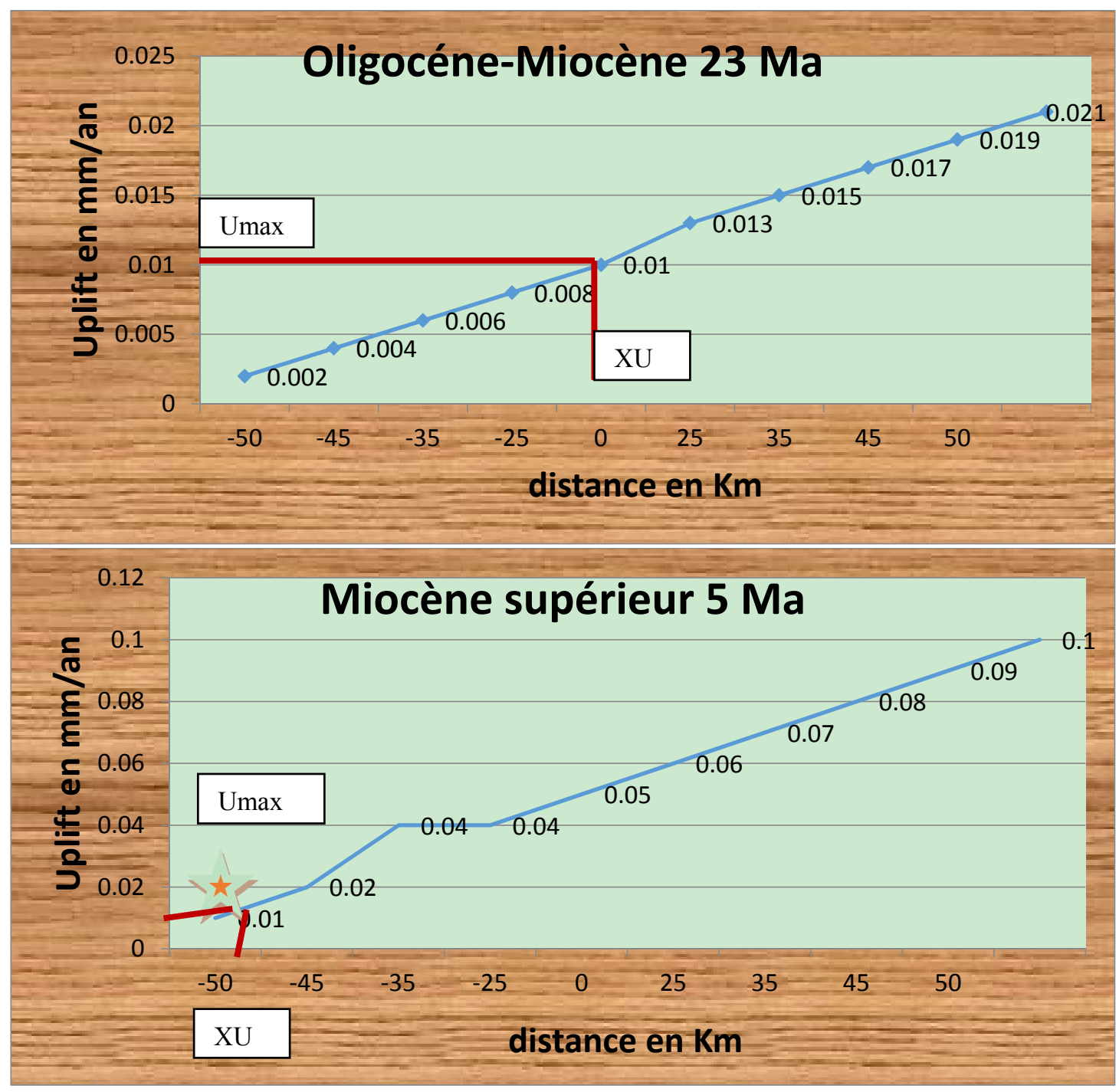

Figure 13. Profile of asymmetric rock uplift rates at different times

In this study, vertical asymmetric rock elevation is considered a proxy for tectonic motion at the groundwater level. Although lateral advection may be important in some asymmetric ranges, the incorporation of this effect requires the addition of more model parameters. These parameters can be solved according to space and time diagrams (Fig. 13). When analyzing these diagrams, where $X_{u}$ represents the location of the rock uplift axis, and $U_{\max }$ represents the maximum rock uplift rate, we find that the rate of rock uplift is uniform in the y direction and constant in time. The initial conditions are a flat relief at an altitude of $0 \mathrm{~m}$, with white noise and a maximum amplitude of $10 \mathrm{~m}$. The altitudes of the eastern and western boundaries are exactly fixed at $0 \mathrm{~m}$ throughout the calculation. During the Eocene (53 Ma) the vertical movement reached its maximum $0.1 \mathrm{~mm}$, for the Oligocene period (33Ma) it decreased to $0.015 \mathrm{~mm} /$ year and kept the same pace until the Oligocene-Miocene transition (23Ma) where it is of the order $0.02 \mathrm{~mm} / \mathrm{year}$. The results show that after the initiation of rock uplift, during the Eocene the mountain grew at about the same rate as the uplift because erosion is very low. The topographic axis, defined here as the line of the highest average elevation, along the north-south profiles, coincides almost exactly with the axis of rock uplift which expresses an Upper Eocene sedimentation stop until the Lower Oligocene. However, as the mountain grows, surface erosion increases, especially on the side of the beach with the highest topographic gradient (from the east). The dynamic equilibrium state is reached before the Oligocene-Miocene transition. The topographic axis therefore migrates gradually towards the center of the mountain. This means that the location of the topographic axis is more strongly affected by the effect of the S-channel gradient than by the drainage zone A, which is larger on the less steep side for the formation of the structural units in a Miocene sedimentary basin. A steady-state dynamic is defined as the condition under which the change in altitude in the Lower Miocene and Upper Miocene periods, averaged over the model area and normalized by the maximum height, is less than $0.01 \%$. 
Before reaching the equilibrium state, the topographic axis migrates about $10 \mathrm{~km}$ from the rock uplift axis towards the center. The elevation of the topographic axis is slightly reduced during this migration.

\section{Conclusions}

The geological history of northern Tunisia is highly dependent on the Tertiary orogenic phases, but the aquifer zones are still a geological mystery. This approach allows us to note another vision on geodynamic evolution. The numerical modeling of the terrain and the model of topographic evolution reveal the following main results:

* The different values for the parameters $\mathrm{Xu}$ and $\mathrm{U}_{\max }$, which describe the rate of rock uplift, were used to determine the dependence of the topography on these parameters. In contrast, the parameters $\mathrm{m}$, $\mathrm{n}$, and $\mathrm{K}$, which control the erosion rate, were initially set at $\mathrm{m}=0.3, \mathrm{n}=0.7$, and $\mathrm{K}=0.11 \times 10^{-2} \mathrm{~mm} / \mathrm{yr}$. These values mean that the current rate of incision has been modeled as a bed function to represent shear stresses.

* $U^{\max }$ uplift parameters were initially set at $0.01 \mathrm{~mm} / \mathrm{yr}$, so a sedimentary gap of 36 billion $\mathrm{m}^{3}$, expressed as a sediment shutdown for 31 million years, could be related to another tectonic phase whose equilibrium state was reached before the Oligocene-Miocene transition.

To better confirm these results we must base future work on numerical modeling and quantification of uplift rates and their variation across deep structures to integrate them into the bedrock models through these structures.

\section{References}

Alouani, R., Ben Ismail-Lattrache, K., Melki, F., \& Talbi, F. (1996). The Upper Eocene prograding folds in the northwest of Tunisia: stratigraphic records and geodynamic significance. Actes des Vèmes Journées d'Exploration Pétrolière. ETAP, 23-33.

Beaudoin, B., Cojan, I., Friès, G., Maillart, J., Parize, O., Pinault, M., \& Truyol, V. (1987). Mesure directe de la compaction dans les sédiments. Notes et Mémoires-Compagnie Française des Pétroles, 21, 235-247.

Ben Ayed, N. (1986). Evolution tectonique de l'avant pays de la chaîne alpine de Tunisie du début du Mésozoïque à l'Actuel. Thèse Sciences, 327.

Ben cheik, L et Moncef Guedderi. (2008). Le bassin versant du jannet (Tunisie) évaluation des risques d'érosion hydrique. M@ppemonde $\mathrm{n}^{\circ} 8$ page 90

Bizuwerk, A., Taddese, G., \& Getahun, Y. (2008). Application of GIS for Modeling Soil Loss Rate in Awash Basin, Ethiopia. International Livestock Research Institute.

Caire, A., \& Coiffait, P. E. (1970). Les dragées de quartz du flysch numidien viennent de la province sarde et non pas de la province saharienne. CR Acad. Sci. Paris, 270, 3181-3183.

Carr, M. D., \& Miller, E. L. (1979). Overthrust emplacement of the Numidian flysch complex in the westernmost Mogod Mountains, Tunisia: Summary. Geological Society of America Bulletin, 90, 513-515. https://doi.org/10.1130/0016-7606(1979)90<513:OEOTNF>2.0.CO;2

Crampon, N. (1971). Etude géologique de la bordure des Mogods, du pays de Bizerte et du nord des Hédil. Unpublished Ph. D. thesis, Nancy I University, France.

Doglioli, A. M. (2011). Circulation Générale en Méditerranée. Océanographie Générale, 101, 1-57.

El Euchi, H., Saidi, M., Fourati, L., \& El Maherssi, Ch. (2004). Northern Tunisia Thrust Belt: Deformation Models and Hydrocarbon Systems. In Swennen, R., Roure, F., \& Grnath, J. W. (Eds.), Deformation, fluid flow, and reservoir appraisal in foreland fold and thrust belts (pp. 371-390). American Association of Petroleum Geologists (AAPG), Hedberg Series, 1.

Frison de Lamotte, D. F., Michard, A., \& Saddiqi, O. (2006). Quelques développements récents sur la géodynamique du Maghreb. Comptes Rendus Geoscience, 338, 1-10. https://doi.org/10.1016/j.crte.2005.11.006

Gallen, S. F., \& Wegmann, K. W. (2017). River profile response to normal fault growth and linkage: an example from the Hellenic forearc of south-central Crete, Greece. Earth Surface Dynamics, 5(1), 161. https://doi.org/10.5194/esurf-5-161-2017

Giachetta, E., \& Willett, S. D. (2018). Effects of river capture and sediment flux on the evolution of plateaus: insights from numerical modeling and river profile analysis in the upper Blue Nile catchment. Journal of Geophysical Research: Earth Surface, 123(6), 1187-1217. https://doi.org/10.1029/2017JF004252

Guerrera, F., Martín - Algarra, A., \& Perrone, V. (1993). Late Oligocene - Miocene syn - / - late - orogenic successions in western and central Mediterranean chains from the Betic Cordillera to the southern Apennines. 
Terra Nova, 5, 525-544. https://doi.org/10.1111/j.1365-3121.1993.tb00302.x

Howard, A. D. (1980). Thresholds in river regimes. In D. R. Coates, \& J. D. Vitek (Eds.), Thresholds in Geomorphology (pp. 227-258). Allen and b Unwin, Concord, Mass. https://doi.org/10.4324/978100302869711

Howard, A. D., Seidl, M. A., \& Dietrich, W. E. (1994). Modeling fluvial erosion on regional to continental scales. Journal of Geophysical Research, 99, 13-971. https://doi.org/10.1029/94JB00744

Kim, J. W., Tchernyshyov, I., Semenza, G. L., \& Dang, C. V. (2006). HIF-1-mediated expression of pyruvate dehydrogenase kinase: a metabolic switch required for cellular adaptation to hypoxia. Cell metabolism, 3, 177-185. https://doi.org/10.1016/j.cmet.2006.02.002

Kirkby, R. J. (1994). Changes in premenstrual symptoms and irrational thinking following cognitive-behavioral coping skills training. Journal of Consulting and Clinical Psychology, 62, 10-26. https://doi.org/10.1037/0022-006X.62.5.1026

Koçyiğit, A. (2013). Nouvelles données de terrain et sismiques sur la déformation par glissement de la plaque intraplaque dans la région de Van, plateau anatolien oriental, E. Turquie. Journal des sciences de la Terre en Asie, 62, 586-605.

Laabidi, A., El Hmaidi, A., Gourari, L., \& El Abassi, M. (2016). Apports Du Modele Numérique De Terrain De La Modélisation Du Relief Et Des Caractéristiques Physiques Du Bassin Versant Du Moyen Entre Amont Du Barrage El Kansera (Sillon Sud Rifain, Maroc). European Scientific Journal, 12, 258. https://doi.org/10.19044/esj.2016.v12n29p258

Mariantonietta, D., Emanuele, G., Domenico, C., \& Luigi, P. (2019). Evolution of fluviokarst canyons in response to the quaternary tectonic uplift of the apulia carbonate platform (southern italy): insights from morphometric analysis of drainage basins. Geomorphology, 6, 1016.

Melki, F., Alouani, R., Boutib, L., Tlig, S., \& Zargouni, F. (2001). La carte géologique de la Tunisie au1/50000, la feuille n. ${ }^{\circ} 2$ de Bizerte. Edition du ServiceGéologique de Tunisie, Office National des Mines.

Melki, F., Ben chelbi, M., Boukadi, N., \& Zargouni, F. (2005). Le rôle des accidents de direction NE-SW dans la structuration de la Tunisie septentrionale. Exemple: le système de faille de Ras El Korane-Béja. 18ème Colloque des Bassins Sédimentaires, 13-14.

Miller, S. R., Slingerland, R. L., \& Kirby, E. (2007). Characteristics of steady state fluvial topography above faultbend folds. Journal of Geophysical Research, 112. https://doi.org/10.1029/2007JF000772

Montgomery, D. R., Mary, P., Goldblum, J. R., \& John, R. (2001). Reproducibility of the diagnosis of dysplasia in Barrett esophagus. A reaffirmation. Human pathology, 4, 368-378. https://doi.org/10.1053/hupa.2001.23510

Ould Bagga, M. A., Abdeljaouad, S., \& Mercier, E. (2006). La « zones des nappes » de Tunisie: une margemésocénozoïque en blocs basculés modérément inversée (région de Taberka/Jendouba; Tunisie nord-occidentle). Bulletin de la Société Géologique de France, 177, 145-154. https://doi.org/10.2113/gssgfbull.177.3.145

Perron, J., \& Royden, L. (2013). An integral approach to bedrock river profile analysis. Earth Surface Processes and Landforms, 38, 570-576. https://doi.org/10.1002/esp.3302

Phillips, J. D. (2018). Historical contingency in fluviokarst landscape evolution. Geomorphology, 303, 41-5. https://doi.org/10.1016/j.geomorph.2017.11.015

Phillips, J. D., \& Lutz, J. D. (2008). convexités de Pro le dans substrat rocheux et ruisseaux alluviaux. Géomorphologie, 102(3), 554-566. https://doi.org/10.1016/j.geomorph.2008.05.042

Pike, R. J., \& Wilson, S. E. (1971). Elevation-relief ratio, hypsometric integral, and geomorphic area-altitude analysis. Geological Society of America Bulletin, 82(4), 1079-1084. https://doi.org/10.1130/00167606(1971)82[1079:ERHIAG]2.0.CO;2

Rehault, J. P., Boillot, G., \& Mauffret, A. (1984). The western Mediterranean basin geological evolution. Marine Geology, 55, 447-477. https://doi.org/10.1016/0025-3227(84)90081-1

Renard, G., Foster, George, R., \& Weesies, G. A. (1997). Prévision de l'érosion des sols par l'eau: guide de planification de la conservation à l'aide de l'équation révisée universelle de la perte de sol (RUSLE). Washington, DC: Département de l'agriculture des États-Unis.

Rouvier, H. (1985). Géologie de l'Extrême Nord tunisien: tectoniques et paléogéographies superposées à l'extrémité orientale de la chaîne nord-maghrébine. Des Mines et de la Géol, 29, 428. 
Rouvier, R. (1977). Mise au point sur le modèle classique d'estimation de la valeur génétique. In Annales de génétique et de sélection animale, 1, 17. https://doi.org/10.1186/1297-9686-9-1-17

Schwanghart, W., \& Scherler, D. (2014). TopoToolbox 2 - MATLAB-based software for topographic analysis and modeling in Earth surface sciences. Earth Surface Dynamics, 2, 1-7. https://doi.org/10.5194/esurf-2-1-2014

Sebei, K. (2008). Etude sismostratigraphique de la plateforme de Halk el Menzel: rampe carbonatée sous contrôle de l'eustatisme et de la tectonique., Thèse Sciences Géologiques, Université Tunis-El Manar, 151.

Stone, R. P., \& Hilborn, D. (2000). Universal Soil Loss Equation (USLE). Ontario Ministry of Agriculture and Food, Agriculture and Rural Division. Factsheet, order, 1, 1198-712.

Talbi, F. (1998). Pétrologie, géochimie, étude des phases fluides et gîtologie liées au magmatisme néogène de la Tunisie septentrionale. Thèse de Doctorat, Université de Tunis II, 368.

Talbi, F., Melki, F., Ismail-Lattrache, K. B., Alouani, R., \& Tlig, S. (2008). Le Numidien de la Tunisie septentrionale: données stratigraphiques et interprétation géodynamique. Estudios Geológicos, 64(1), 31-44. https://doi.org/10.3989/egeol.08641429

Tlig, S., Sahli, S., Er-Raioui, L., Alouani, R., \& Mzoughi, M. (2010). Depositional environment controls on petroleum potential of the Eocene in the North of Tunisia. Journal of Petroleum Science and Engineering, 71(3-4), 91-105. https://doi.org/10.1016/j.petrol.2010.01.009

Watts, J. D., Gauss, J., \& Bartlett, R. J. (1993). Coupled - cluster methods with noniterative triple excitations for restricted open - shell Hartree-Fock and other general single determinant reference functions, Energies and analytical gradients. The Journal of chemical physics, 98, 8718-8733. https://doi.org/10.1063/1.464480

Whipple, K. X. (2004). Bedrock rivers and the geomorphology of active orogens. Annual Review of Earth and Planetary Sciences, 32, 151-185. https://doi.org/10.1146/annurev.earth.32.101802.120356

Whipple, K. X., \& Tucker, G. E. (1999). Dynamics of the stream-power river incision model: Implications for height limits of mountain ranges, landscape response timescales, and research needs. J. Geophys. Res, 104, 661-674. https://doi.org/10.1029/1999JB900120

Whipple, K. X., \& Tucker, G. E. (2002). Implications of sediment - flux - dependent river incision models for landscape evolution. Journal of Geophysical Research: Solid Earth, 107(B2). https://doi.org/10.1029/2000JB000044

Wildi, W. (1983). La chaîne tello-rifaine (Algérie, Maroc, Tunisie), structure, stratigraphie et évolution du Trias au Miocène. Revue de géographie physique et de géologie dynamique, 24, 201-297.

Willett, S. D., Mccoy, S. W., Perron, J. T., Goren, L., \& Chen, C. Y. (2014). Dynamic reorganization of river basins. Science, 343. https://doi.org/10.1126/science.1248765

Willgoose, G., Bras, R. L., \& Rodriguez - Iturbe, I. (1991). A coupled channel network growth and hillslope evolution model: 1. Theoryn. Water Resources Research, 27, 1671-1684. https://doi.org/10.1029/91WR00935

Wischmeier, W. H., \& Smith, D. D. (1978). Predicting rainfall erosion losses-a guide to conservation planning. Predicting rainfall erosion losses-a guide to conservation planning.

Yaich, C., Durlet, C., \& Renard, M. (2000). Corrélation stratigraphique entre les unités oligo-miocènes de Tunisie centrale et le Numidien. Comptes Rendus de l'Académie des Sciences-Series IIA-Earth and Planetary Science, 331(7), 499-506. https://doi.org/10.1016/S1251-8050(00)01443-9

Yang, R., Willett, S. D., \& Goren, L. (2015). In situ low-relief landscape formation as a result of river network disruption. Nature, 520, 526-529. https://doi.org/10.1038/nature14354

\section{Copyrights}

Copyright for this article is retained by the author(s), with first publication rights granted to the journal.

This is an open-access article distributed under the terms and conditions of the Creative Commons Attribution license (http://creativecommons.org/licenses/by/4.0/). 